\title{
Yield and crop cycle time of peaches cultivated in subtropical climates and subjected to different pruning times
}

\author{
Produtividade e sazonalidade de pessegueiros cultivados em \\ condições subtropicais, sujeitos a diferentes épocas de poda
}

\author{
Rafael Augusto Ferraz ${ }^{1 *}$; Sarita Leonel2; Daniela Mota Segantini ${ }^{3}$; \\ Marco Antonio Tecchio ${ }^{2}$; Luis Eduardo Corrêa Antunes ${ }^{4}$
}

\begin{abstract}
The cultivation of peaches in regions of subtropical and tropical climate is currently achieved through a set of practices such as using less demanding cultivars in cold conditions, applying plant growth regulators to break dormancy, and performing specific pruning, like production and renewal pruning. Research on the climate adaptation of cultivars is of great importance in establishing a crop in a given region. Therefore, the objective of this study was to evaluate the agronomic performance of three cultivars subjected to different production pruning times in Botucatu/SP, where 2-year old peach trees were evaluated, grown at a spacing of $6.0 \times 4.0$ meters. The experimental design was a split plot design with four blocks, using the cultivars Douradão, BRS Kampai and BRS Rubimel, and the subplots corresponded to pruning times in May, June, July and August. Ten plants were used per plot, with the four central plants considered useful and the remaining considered as margins. Pruning in June and July showed the best results in terms of percentage of fruit set and production. The cultivar BRS Rubimel showed the best percentage of fruit set when pruned in June (44.96\%), and best fruit production when pruned in July (18.7 kg plant ${ }^{-1}$ ). Pruning in May anticipated the harvest of cultivar BRS Rubimel by 13 days whereas pruning carried out in July and August provided late harvests for cultivars Douradão and BRS Kampai.
\end{abstract}

Key words: Agronomic performance, peach, production pruning, Prunus persica, regional behavior

\section{Resumo}

O cultivo de pêssegos, em regiões de clima subtropical e tropical, é conseguido atualmente através de um conjunto de práticas como o uso de cultivares menos exigentes em frio, a aplicação de reguladores vegetais para a quebra da dormência, e a realização de podas específicas, nomeadamente as de produção e de renovação. Os ensaios de aptidão climática de cultivares são de grande importância para o estabelecimento de uma cultura numa determinada região. Este trabalho teve como objetivo avaliar o comportamento agronômico de três cultivares de pessegueiro submetidas a diferentes épocas de poda de frutificação em Botucatu/SP, onde foram avaliados pessegueiros com dois anos de idade, cultivados no espaçamento de $6,0 \times$ x 4,0 m. O delineamento foi em parcelas subdivididas, com quatro blocos, utilizando-se as cultivares Douradão, BRS Kampai e BRS Rubimel, sendo as subparcelas

\footnotetext{
${ }^{1}$ Discente do Curso de Doutorado em Horticultura, Faculdade de Ciências Agronômicas, Universidade Estadual Paulista 'Júlio de Mesquita Filho', UNESP, Botucatu, SP, Brasil. E-mail: rafaelferraz86@hotmail.com

2 Profs. Drs., Faculdade de Ciências Agronômicas, UNESP, Botucatu, SP, Brasil. E-mail: sarinel@fca.unesp.br; tecchio@fca. unesp.br

3 Eng $^{\mathrm{a}}$ Agr $^{\mathrm{a}}$, Dr ${ }^{\mathrm{a}}$, Faculdade de Ciências Agronômicas, UNESP, Botucatu, SP, Brasil. E-mail: dani_segantini@hotmail.com

${ }^{4}$ Pesquisador, EMBRAPA Clima Temperado, Pelotas, RS, Brasil. E-mail: luis.antunes@embrapa.br

* Author for correspondence
} 
correspondendo às épocas de poda em maio, junho, julho e agosto. Foram utilizadas 10 plantas por parcela experimental, sendo as quatro centrais consideradas plantas úteis e as demais consideradas bordadura. As podas realizadas em junho e julho apresentaram os melhores resultados em termos de porcentagem de fixação de frutos e produção por planta. A cultivar BRS Rubimel apresentou maior porcentagem de fixação quando podada em junho (44.96\%) e maior produção de frutos quando podada em julho (18.70 kg planta $\left.{ }^{-1}\right)$. A poda realizada em maio antecipou a colheita da cultivar BRS Rubimel em 13 dias, enquanto que podas realizadas em julho e agosto proporcionaram uma colheita tardia para as cultivares Douradão e BRS Kampai.

Palavras-chave: Comportamento regional, desempenho agronômico, pêssego, poda de produção, Prunus persica

\section{Introduction}

Peach, a fruit belonging to the family Rosaceae, grows in temperate climate, and has strict requirements concerning chilling hours $\left(<7.2^{\circ} \mathrm{C}\right)$. However, the development of genetic improvement techniques and the use of plant growth regulators have allowed the expansion of peach culture to subtropical and tropical regions.

According to Fachinello et al. (2011), from 1999 to 2009 , the Brazilian peach production increased $64.69 \%$, whereas the harvested area decreased $15.39 \%$. These variations were mainly due to an improvement in average yield, which increased from 5,833 $\mathrm{kg} \mathrm{ha}^{-1}$ in 1999 to $11,355 \mathrm{~kg} \mathrm{ha}^{-1}$ in 2009 , meaning there was a $94.67 \%$ increase during this period. Furthermore, according to these authors, the main peach producing states are, in a descending order of yield, Rio Grande do Sul (65.1\%), São Paulo (14.0\%), Minas Gerais (11.8\%), Paraná $(7.5 \%)$, and Santa Catarina (1.6\%).

In 2012, peach production in Brazil reached $232,987 \mathrm{t}$, and occupied an area of 19,155 ha; the South region was the main producer, with $175,159 \mathrm{t}$, followed by the Southeast region, with $57,828 \mathrm{t}$. In São Paulo (SP), the cultivated area was 1,680 ha in 2012 , with a production of $37,633 \mathrm{t}$ (IBGE, 2012).

According to Pereira and Mayer (2008), regions with warmer climates, such as the north-central state of São Paulo, can only be consolidated as highquality peach producers if cultivars or more locally adapted varieties are used.
When grown in regions with insufficient cold winter, peach trees may show delayed and longer flowering seasons, lower percentages of flowering and budding, and consequently, reduced production with uneven and low-quality fruits, which are characteristic of poorly adapted plants (CITADIN et al., 2006). In São Paulo, the harvest of ripe peaches begins earlier than that in the southern states of Brazil, because of the warmer winter climate, the use of own cultivars, and special subsidiary cultivation techniques (PEDRO JÚNIOR et al., 2007).

According to Antunes (2002), the anticipation of the fruit supply, either by crop management or by the climatic conditions in a region, can create advantageous market opportunities for the fruit grower.

With favorable climatic conditions and the use of suitable varieties, it would be possible to increase peach production. Therefore, this study evaluates the agronomic performance of the cultivars Douradão, BRS Kampai, and BRS Rubimel subjected to four pruning times, with the aim of finding which would result in a higher seasonal supply of peaches in the subtropical climate region of São Paulo.

\section{Material and Methods}

The experiment was conducted in Botucatu/SP $\left(22^{\circ} 51^{\prime} 55^{\prime \prime} \mathrm{S}, 48^{\circ} 26^{\prime} 22^{\prime \prime} \mathrm{W}\right)$ at $810 \mathrm{~m}$ altitude, during the 2011/2012 agricultural cycle. The climate, according to the Koppen classification, is mesothermal ( $\mathrm{Cwa}$ ) i.e., humid subtropical with dry 
periods during winter, rain from November to April, and an average rainfall of $1,433 \mathrm{~mm} \mathrm{y}^{-1}$. The relative humidity of this area is $71 \%$ and the average annual temperature is $19.3^{\circ} \mathrm{C}$. Three cultivars-Douradão, BRS Kampai, and BRS Rubimel—were evaluated in this study.

'Douradão': originating from Dourado-1 free pollination (Tutu $\times$ Maravilha) in 1998, this cultivar is currently one of the main cultivars grown in São Paulo. It has medium vigor and compact growth with maturation occurring in mid-October. Its chilling requirement is up to 200 hours. It has a sweet-sour flavor, with a content of soluble solids around $16{ }^{\circ}$ Brix and $\mathrm{pH} 4.5$ (BARBOSA et al., 2000).

'BRS Kampai': originating from controlled hybridization between cultivars Chimarrita and Flordaprince, it was presented by Embrapa Clima Temperado in 2009. This cultivar is adapted to locations with approximately 200 chilling hours (RASEIRA et al., 2010), has white and green pulp, and the fruit weighs between 110 and $120 \mathrm{~g}$ (SCARANARI et al., 2009). Its maturation begins in mid-October in São Paulo, hence earlier than 'BRS Rubimel'. The content of soluble solids ranges between 9 and $13{ }^{\circ}$ Brix, most commonly between 11 and $12{ }^{\circ}$ Brix (RASEIRA et al., 2010).

'BRS Rubimel': launched in 2007, it developed from seeds resulting from the hybridization between cultivars Chimarrita and Flordaprince performed in 1991. It is estimated that BRS Rubimel chilling requirements range from 200 to 300 hours, which is lower than that of Chimarrita. Ripening occurs between the second half of October (São Paulo) and early November (Rio Grande do Sul) (SCARANARI et al., 2009).

Two-year-old plants were placed in the "cup" system, with four main limbs and spaced at $6.0 \times$ $4.0 \mathrm{~m}$. The "Okinawa" rootstock was used for all cup cultivars. The seedlings, provided by Embrapa Clima Temperado, were obtained from "Frutplan Mudas Ltda" (Renasem RS 0099/2005), Pelotas, Rio
Grande do Sul. The experimental design consisted of a split plot with four blocks, with each plot corresponding to one of the cultivars (Douradão, BRS Kampai and BRS Rubimel), and the subplots of pruning times in May, June, July and August. Ten plants were used per experimental plot; the four central plants were considered useful, whereas the other six served as a barrier between plots. Data were subjected to an analysis of variance, and means were compared by Tukey's test, considering a 0.05 significance level.

Fruit pruning was performed on the $20^{\text {th }}$ day of May, June, July, and August. Immediately after, plant dormancy was broken using $0.6 \%$ hydrogen cyanamide $\left(\right.$ Dormex $\left.^{\circledR}\right)+1 \%$ mineral oil $\left(\right.$ Assist $\left.{ }^{\circledR}\right)$, which was applied by spraying the plants up to the run-off point. About two weeks after full bloom, fruit thinning was performed, leaving and 2-5 fruits per branch depending on the thickness and size of the branches.

Six segments of $25 \mathrm{~cm}$ were randomly distributed over the circumference formed by each treetop within each plot and associated to tree branches. The number of flowering buds and set fruits was counted in each of these branches at 15 days after pruning and 15 days after full bloom, respectively. Fruit setting, expressed in \% setting, was determined as follows: $\%$ Setting $=$ (number of set fruits $/$ number of flowering buds) $\times 100$.

Yield, in $\mathrm{kg} \mathrm{plant}^{-1}$, was determined as the product of the total number of fruits by the fresh weight of fruits per plant; estimated yield was expressed in $\mathrm{t} \mathrm{ha}^{-1}$, considering a planting density of 417 plants ha ${ }^{-1}$. The beginning and end dates of the harvest were recorded for each plant, as well as the total number of harvest days, in order to find the peak of peach production.

During the experiment, phytosanitary treatments and fertilization were applied to ensure plant health. Management techniques recommended for peach production, such as weeding, pruning, and fruit bagging, were also performed when required. 


\section{Results and Discussion}

Douradão, BRS Kampai, and BRS Rubimel produced 10.76, 12.71, and 10.41 flowering buds, respectively (Table 1), which are lower values than those found in the literature. Segantini (2010) evaluated seven different peach cultivars in the region of São Manuel - SP and obtained 20.33 flowering buds on $25-\mathrm{cm}$ branches for the cultivar
Douradão. According to Raseira and Nakasu (1998), cultivars Chiripá, Marli, and Granada had an average of 24 to 28 flowering buds on 25 $\mathrm{cm}$ branches. Pereira and Mayer (2008) reported 23.23 and 31.50 flowering buds per $30 \mathrm{~cm}$ branch (2005 and 2006, respectively) for the cultivar Regis in the region of Jaboticabal - SP, which practically corresponds to a flowering bud for each centimeter.

Table 1. Values of flowering buds, fruit set in $25-\mathrm{cm}$ branches and yield $\left(\mathrm{t} \mathrm{ha} \mathrm{h}^{-1}\right)$ for three peach cultivars under four pruning times. Botucatu, SP, 2012.

\begin{tabular}{|c|c|c|c|}
\hline Cultivar & Flowering buds & Number of fruits set & Yield \\
\hline Douradão & $10.76 \mathrm{a}$ & $2.81 \mathrm{a}$ & $1.18 \mathrm{a}$ \\
\hline BRS Kampai & $12.71 \mathrm{a}$ & $2.52 \mathrm{a}$ & $2.07 \mathrm{a}$ \\
\hline BRS Rubimel & $10.41 \mathrm{a}$ & $2.14 \mathrm{a}$ & $2.43 \mathrm{a}$ \\
\hline DMS & 6.51 & 1.87 & 1.83 \\
\hline Pruning times & Flowering buds & Number of fruits set & Yield \\
\hline May & $11.49 \mathrm{a}$ & $1.10 \mathrm{~b}$ & $0.52 \mathrm{~b}$ \\
\hline June & $11.84 \mathrm{a}$ & $4.10 \mathrm{a}$ & $3.07 \mathrm{a}$ \\
\hline July & $10.94 \mathrm{a}$ & $3.48 \mathrm{a}$ & $3.54 \mathrm{a}$ \\
\hline August & $10.91 \mathrm{a}$ & $1.29 \mathrm{~b}$ & $0.44 \mathrm{~b}$ \\
\hline DMS & 3.6 & 1.61 & 1.51 \\
\hline
\end{tabular}

Means followed by the same letter in the column do not differ by the Tukey test at $5 \%$ probability.

The number of set fruits showed no differences among cultivars; however, there were variations related to pruning times, with the highest values of set fruits obtained when pruning occurred in June and July.

Pruning carried out in May and August resulted in the lowest number of set fruits. In the first case, the low numbers might be attributed to a short accumulation of chilling hours $(\mathrm{NCH})$ until the time of pruning $(0.0$ hours $<7.2^{\circ} \mathrm{C}$ and 25.3 hours $<13.0^{\circ} \mathrm{C}$ ) (Table 2). A high chilling deficiency leads to a very weak shoot growth and reduces plant vigor: flowers are small and deformed, resulting in less effective fructification with smaller fruits; peach trees also show a sharp suture or tip (PETRI; HERTER, 2004).

The accumulation of $\mathrm{NCH}$ in August was higher than that in May $\left(0.0\right.$ hours $<7.2^{\circ} \mathrm{C}$ and 252.7 hours $<13.0^{\circ} \mathrm{C}$ ) (Table 2 ), and therefore, there might be another reason for the low number of set fruits associated to pruning in August. This was a late month to perform pruning since budding and flowering had already occurred in virtually all plants by that time, which may have damaged the fruit-setting process. Furthermore, the application of hydrogen cyanamide burned the buds, resulting in a reduction in fruit set (Table 1). Another factor to be considered in explaining the reduction of fruits set per plant is water deficiency, since there was no rainfall in August (Table 2). This might have contributed to an early falling of flowers in the plants that were pruned at this time, thus highlighting the need for orchard irrigation in periods of low precipitation. 
Table 2. Monthly means of average temperatures $\left({ }^{\circ} \mathrm{C}\right)$, rainfall $(\mathrm{mm})$, and number of chilling hours, $<7 \mathrm{C}$ and $<13^{\circ} \mathrm{C}$. Botucatu, SP, 2012.

\begin{tabular}{ccccc}
\hline Month and Year & $\begin{array}{c}\text { Average } \\
\text { temperature }\left({ }^{\circ} \mathbf{C}\right)\end{array}$ & Rainfall $(\mathbf{m m})$ & $\mathbf{N C H}<\mathbf{7}^{\circ} \mathbf{C}$ & $\mathbf{N C H}<\mathbf{1 3}^{\circ} \mathbf{C}$ \\
\hline Jan/12 & 20.7 & 357.3 & 0 & 0 \\
Feb/12 & 23.9 & 166.8 & 0 & 0 \\
Mar/12 & 22.3 & 58.9 & 0 & 0 \\
Apr/12 & 20.9 & 250.1 & 0 & 1.8 \\
May/12 & 17.7 & 78.1 & 0 & 23.5 \\
June/12 & 17.1 & 228.4 & 0 & 62.2 \\
July/12 & 17.5 & 22.9 & 0 & 137.7 \\
Aug/12 & 19.2 & 0.0 & 0 & 29.3 \\
Sept/12 & 20.7 & 158.9 & 0 & 52.7 \\
Oct/12 & 22.8 & 104.1 & 0 & 2.3 \\
Nov/12 & 21.4 & 419.1 & 0 & 0 \\
Dec/12 & 23.5 & 0 & 0 \\
\hline
\end{tabular}

Source: Departamento de Ciências Ambientais, FCA - UNESP - Botucatu/SP.

There was a significant interaction between cultivars and pruning times when considering the percentage of fruit setting, number of fruits per plant, and fruit production (Table 3 ). Pruning performed during June and July resulted in higher fruit setting percentages, number of fruits per plant and fruit production for the three cultivars. For BRS Kampai, the fruit setting percentages obtained with pruning performed in June and July were $29.61 \%$ and $27.68 \%$, respectively, whereas for cultivar Douradão the fruit setting percentages obtained with pruning performed in June and July were $24.86 \%$ and $39.48 \%$, respectively. For BRS Rubimel the highest fruit setting percentage (44.96\%) was obtained with pruning performed in June.

The values found in this study are consistent with those found in the literature. According to Barbosa et al. (1997), fruit setting percentages ranged from 10 to $55 \%$ for different peach cultivars. In Itapeva - SP, the fruit setting percentages reported for cultivars 'Douradão' and 'Aurora-1' were 44.9\% and 57.5\%, respectively (BARBOSA et al., 1999).
Pruning performed in June and July provided the highest production values for cultivars Douradão and BRS Kampai: 9.47 and $8.72 \mathrm{~kg}$ plant $^{-1}$ in June, and 9.64 and $7.78 \mathrm{~kg} \mathrm{plant}^{-1}$ in July, respectively. For cultivar BRS Rubimel, the highest production value (18.70 kg plant $\left.{ }^{-1}\right)$ was obtained with pruning performed in July. Very early pruning, performed in May, and late pruning, performed in August, led to a decrease in production for all cultivars (Table 3 ). These results corroborate the findings of Raseira and Pereira (2003), which suggest that pruning should be performed neither too early, to avoid inducing early budding, nor too late, to prevent losing reserves within the buds removed by pruning. Pruning is therefore recommended to be performed during the bud swelling period.

When pruning was performed at the most appropriate time (June and July), production values ranged between 7.60 and $18.70 \mathrm{~kg}$ plant $^{-1}$ (Table $3)$. These values are in agreement with the values of 6.91 and $22 \mathrm{~kg}$ plant ${ }^{-1}$ observed by Pereira and Mayer (2008) in the region of Jaboticabal - SP, for selection Jab 694 and cultivar 'Aurora-1', in their second year of production. 
Table 3. Values for fruit setting (\%), $\mathrm{n}^{\mathrm{o}}$ of fruits per plant and yield $\left(\mathrm{kg} \mathrm{plant}^{-1}\right)$ of three peach cultivars under four pruning times. Botucatu, SP, 2012.

\begin{tabular}{|c|c|c|c|}
\hline \multicolumn{4}{|c|}{ Fruit setting (\%) } \\
\hline & & Cultivar & \\
\hline Pruning time & Douradão & BRS Kampai & BRS Rubimel \\
\hline May & $11.13 \mathrm{bA}$ & $12.4 \mathrm{bcA}$ & $9.76 \mathrm{bA}$ \\
\hline June & $24.86 \mathrm{abB}$ & $29.61 \mathrm{aB}$ & $44.96 \mathrm{aA}$ \\
\hline July & $39.48 \mathrm{aA}$ & $27.68 \mathrm{abAB}$ & $23.21 \mathrm{bB}$ \\
\hline \multirow[t]{3}{*}{ August } & $33.11 \mathrm{aA}$ & $6.81 \mathrm{cB}$ & $7.51 \mathrm{bB}$ \\
\hline & $n^{0}$ fruits $p$ & & \\
\hline & & Cultivar & \\
\hline Pruning time & Douradão & BRS Kampai & BRS Rubimel \\
\hline May & $18.00 \mathrm{bA}$ & $22.75 \mathrm{bA}$ & $20.66 \mathrm{cA}$ \\
\hline June & $115.00 \mathrm{aA}$ & $120.33 \mathrm{aA}$ & $70.00 \mathrm{bB}$ \\
\hline July & $111.55 \mathrm{aB}$ & $98.66 \mathrm{aB}$ & $192.66 \mathrm{aA}$ \\
\hline \multirow[t]{3}{*}{ August } & $13.00 \mathrm{bA}$ & $23.33 \mathrm{bA}$ & $12.00 \mathrm{cA}$ \\
\hline & Yield & & \\
\hline & & Cultivar & \\
\hline Pruning time & Douradão & BRS Kampai & BRS Rubimel \\
\hline May & $1.42 \mathrm{bA}$ & $1.60 \mathrm{bA}$ & $1.63 \mathrm{cA}$ \\
\hline June & $9.47 \mathrm{aA}$ & $9.64 \mathrm{aA}$ & $7.60 \mathrm{bA}$ \\
\hline July & $8.72 \mathrm{aB}$ & $7.78 \mathrm{aB}$ & $18.70 \mathrm{aA}$ \\
\hline August & $0.97 \mathrm{bA}$ & $2.16 \mathrm{bA}$ & $1.13 \mathrm{cA}$ \\
\hline
\end{tabular}

Means followed by the same letter, lowercase in columns (pruning times) and uppercase in rows (cultivars), do not differ by the Tukey test at $5 \%$ probability.

The values obtained in this study are also similar to those presented by Leonel and Tecchio (2011), who obtained average production values of 14.9 and $13.8 \mathrm{~kg}$ plant $^{-1}$ for all cultivars with pruning performed in July, in 2009 and 2010, respectively. These authors also reported values of 16.5 and $12.8 \mathrm{~kg} \mathrm{plant}^{-1}$ for 'Douradão' in 2009 and 2010, respectively.

When pruning was performed in May, harvest was anticipated for the three cultivars, starting on October 18, 13 days earlier for cultivars Douradão and BRS Kampai and 19 days earlier for BRS Rubimel than when pruning was performed in June (Table 4). In addition to the earlier harvest date, BRS Kampai and BRS Rubimel plants that were pruned in May showed longer harvest periods; for 'Douradão', the longest harvest period was obtained when the plants were pruned in June.

In the present study, cultivars pruned in July had, on average, 8 or 5 harvest days (Douradão and BRS Rubimel in the first case and BRS Kampai in the second). These numbers are much lower than those reported by Leonel and Tecchio (2011), who obtained 19.5 harvest days, on average, for various cultivars pruned in July. In addition, according to these authors, the harvest of Douradão pruned in July lasted from October 30 to November 4 in 2009 and from October 10 to November 7 in 2010, which is slightly earlier than that found in the present study (November 6 to 14). This might be attributed to different weather conditions, but also to the age of the plants studied by Leonel and Tecchio (2011); the plants were 6 years old, and thus, were 4 years older than the ones used in the present study. 
Table 4. Harvest periods of three peach cultivars under four pruning times. Botucatu - SP, 2012.

\begin{tabular}{|c|c|c|c|c|c|c|c|c|c|}
\hline Douradão & 18/out & 23/out & 29/out & 31/out & $03 /$ nov & 06/nov & 10/nov & $14 /$ nov & $19 /$ nov \\
\hline \multicolumn{10}{|l|}{ May } \\
\hline \multicolumn{10}{|l|}{ June } \\
\hline \multicolumn{10}{|l|}{ July } \\
\hline \multicolumn{10}{|l|}{ August } \\
\hline BRS Kampai & $18 /$ out & 23/out & 29/out & 31/out & $03 /$ nov & 06/nov & $10 /$ nov & $14 /$ nov & $19 /$ nov \\
\hline \multicolumn{10}{|l|}{ May } \\
\hline \multicolumn{10}{|l|}{ June } \\
\hline \multicolumn{10}{|l|}{ July } \\
\hline \multicolumn{10}{|l|}{ August } \\
\hline BRS Rubimel & 18/out & 23/out & 29/out & 31/out & $03 /$ nov & 06/nov & $10 /$ nov & $14 /$ nov & $19 /$ nov \\
\hline \multicolumn{10}{|l|}{ May } \\
\hline \multicolumn{10}{|l|}{ June } \\
\hline \multicolumn{10}{|l|}{ July } \\
\hline August & & & & & & & & & \\
\hline
\end{tabular}

Chalfun et al. (2002) evaluated the effects of irrigation, $0.7 \%$ hydrogen cyanamide and four pruning times in the harvest of cultivar Diamante in the region of Lavras, Minas Gerais. The authors found that pruning performed in the first half of May, with or without irrigation, provided an advance of 30-40 days in peach harvest when compared with the traditional harvest season for this cultivar in the region (first half of November, in which trees are pruned in the second half of June).

The anticipation of pruning can become an option for producers, since, despite resulting in a lower production than pruning trees in June and July, this practice allows to anticipate harvest and hence fruit supply, even in the off-season. Moreover, pruning performed in July and August provided a late harvest for cultivars Douradão and BRS Kampai (early November instead of October in the state of São Paulo), enabling a longer harvest season for the same cultivar and better seasonality in product supply, which might result in the possibility of obtaining better market prices.

\section{Conclusions}

Pruning in May, June, July and August allowed increasing the harvest season of peach trees from cultivars Douradão, BRS Kampai, and BRS Rubimel; nevertheless, pruning carried out in May and August caused a drastic reduction in production. Thus, further studies are necessary in order to adjust agricultural practices, such as the dosage of plant growth regulators used in dormancy breaking, to compensate for production reduction.

For cultivars Douradão and BRS Kampai, production pruning should be performed in June and July, whereas for cultivar BRS Rubimel, it should occur only in July.

'BRS Kampai' and 'BRS Rubimel' are promising cultivars for peach production in Botucatu - SP as they showed similar yields to 'Douradão', when pruned in June and July; 'Douradão' is a cultivar already established in the region.

\section{Acknowledgements}

The authors would like to thank Embrapa Clima Temperado, Pelotas/RS for the supply of seedlings and for all the help during the experiments. 


\section{References}

ANTUNES, L. E. C. Amora-preta: nova opção de cultivo no Brasil. Ciência Rural, Santa Maria, v. 32, n. 1, p. 151158, 2002.

BARBOSA, W.; OJIMA, M.; CAMPO DALL'ORTO, F. A. Pêssego 'Douradão'. In: DONADIO, L. C. (Ed.). Novas variedades brasileiras de frutas. Jaboticabal: Sociedade Brasileira de Fruticultura, 2000. p. 176-177.

BARBOSA, W.; OJIMA, M.; CAMPO DALL'ORTO, F. A. Comportamento do pessegueiro "Douradão" em Itupeva. Scientia Agrícola, Piracicaba, v. 56, n. 4, p. 1261-1265, 1999.

BARBOSA, W.; OJIMA, M.; DALL'ORTO, F. A. C.; MARTINS, F. P.; CASTRO, J. L.; SANTOS, R. R. Avaliação de pessegueiros e nectarineiras introduzidos no Brasil, procedentes da Flórida, EUA. Scientia Agricola, Piracicaba, v. 54, n. 3, p. 152-159, 1997.

CHALFUN, N. N. J.; HOFFMANN, A.; ANTUNES, L. E. C. Efeito da irrigação e da poda hibernal na antecipação da colheita do pêssego 'Diamante'. Ciência e Agrotecnologia, Lavras, v. 26, n. 1, p. 204-210, 2002.

CITADIN, I.; BASSANI, M. H.; DANNER, M. A.; MAZARO, S. M.; GOUVÊA, A. Uso de cianamida hidrogenada e óleo mineral na floração, brotação e produção do pessegueiro "Chiripá". Revista Brasileira de Fruticultura, Jaboticabal, v. 28, n. 1, p. 32-35, 2006.

FACHINELLO, J. C.; PASA, M. S.; SCHMTIZ, J. D.; BETEMPS, D. L. Situação e perspectivas da fruticultura de clima temperado no Brasil. Revista Brasileira de Fruticultura, Jaboticabal, v. 33, n. 1, p. 109-120, 2011.

INSTITUTO BRASILEIRO DE GEOGRAFIA E ESTATÍSTICA - IBGE. Produção agrícola municipal: culturas temporárias e permanentes. Rio de Janeiro: IBGE, 2012. v. 39, p. 1-98.

LEONEL, S.; TECCHIO, M. A. Produção e sazonalidade de pessegueiro e nectarineira sob florescimento espontâneo e com cianamida hidrogenada e óleo mineral. Revista Brasileira de Fruticultura, Jaboticabal, p. E. 227-234, 2011. Número Especial.
PEDRO JÚNIOR, M. J.; BARBOSA, W.; ROLIM, G. S.; CASTRO, J. L. de. Época de florescimento e horas de frio para pessegueiros e nectarineiras. Revista Brasileira de Fruticultura, Jaboticabal, v. 29, n. 3, p. 425-430, 2007.

PEREIRA, F. M.; MAYER, N.A. Fenologia e produção de gemas em cultivares e seleções de pessegueiro na região de Jaboticabal-SP. Revista Brasileira de Fruticultura, Jaboticabal, v. 30, n. 1, p. 43-47, 2008.

PETRI, J. L.; HERTER, F. G. Dormência e indução à brotação. In: MONTEIRO, L. B.; MAY DE MIO, L. L.; SERRAT, B. M.; MOTTA, A. C.; CUQUEL, F. L. (Ed.). Fruteiras de caroço: uma visão ecológica. Curitiba: UFPR, 2004. p. 119-127.

RASEIRA, A.; PEREIRA, J. F. M. Poda. In: RASEIRA, M. do C. B.; CENTEllas-QUEZADA, A. Pêssego. Produção. EMBRAPA Clima Temperado (Pelotas). Brasília: EMBRAPA Informação Tecnológica, 2003. 162 p.

RASEIRA, M. do C. B.; NAKASU, B. H.; UENO, B.; SCARANARI, C. Pessegueiro: Cultivar BRS Kampai. Revista Brasileira de Fruticultura, Jaboticabal, v. 32, n. 4, p. 1275-1278, 2010.

RASEIRA, M. C. B.; NAKASU, B. H. Cultivares. In: MEDEIROS, C. A. B.; RASEIRA, M. do C. B. (Ed.). A cultura do pessegueiro. Pelotas: EMBRAPA, SPI; Brasília: EMBRAPA - CPACT, 1998. p. 29-98.

SCARANARI, C.; RASEIRA, M. do C. B.; FELDBERG, N. P.; BARBOSA, W.; MARTINS, F. P. Catálogo de cultivares de pêssego e nectarina. Pelotas: EMBRAPA Clima Temperado, 2009. 136 p.

SEGANTINI, D. M. Fenologia, produção e qualidade dos frutos de cultivares de pessegueiro (Prunus persica L. Bastch) em São Manuel - SP. 2010. Dissertação (Mestrado em Agronomia, Horticultura) - Faculdade de Ciências Agronômicas. Universidade Estadual Paulista Júlio de Mesquita Filho, Botucatu. 